\title{
A typology of Pākehā 'Whiteness' in education
}

\author{
Georgina Tuari Stewart
}

ORCID: 0000-0001-8832-2415

georgina.stewart@aut.ac.nz

School of Education, Auckland University of Technology, Auckland, New Zealand

\begin{abstract}
This article presents a typology to unpack the notion of 'Whiteness' as it operates in contemporary Māori-Pākehā relationships in Aotearoa New Zealand, within social domains such as education. This five-point typology of Whiteness aims to include the main positions commonly taken by Pākehā in their dealings with Māori in education. The names of these five positions depict, with dramatic effect, the central orientation of each one: Exterminator, Overlord, Vampire, Savior/Saviour, and Ally. An important disclaimer about this typology is that it relates to attitudes and ideas, not persons. Most people tend to hold individualised and changeable mixes of attitudes and ideas about complex social scenarios such as intercultural relationships, so such a typology cannot and is not intended to 'classify' people. It must be noted, however, that only the Ally position is politically robust, in terms of countering White Privilege and providing authentic support for Māori interests. Given the complicated issues involved, this typology may help Pākehā and Māori scholars in education and related fields to generate new insights about the range of attitudes held by Pākehā towards Māori things. Such a typology may even help encourage some Pākehā to commit to undertaking the work required to shift towards the kinds of understanding and attitudes characteristic of White Allies.
\end{abstract}

\section{Introduction}

The concept of 'Whiteness' forms part of contemporary debates about racism, which acknowledge the structural levels at which racism works, over and above the attitudes and beliefs of individuals (Bonilla-Silve, 2005). Whiteness acts as an umbrella concept for a number of cognate terms, including White Privilege (McIntosh, 1989), White Supremacy (Dorrien, 2018; McGettigan, 2019), White Fragility (DiAngelo, 2018), etc. Fundamental to the meaning of all Whiteness terms is the recognition that being White is the norm still operating today, in Britain and its settler ex-colonies, in particular Canada, Australia, New Zealand and the US (collectively known as the CANZUS countries). Thus, White Privilege is inherent in the concept of Whiteness, since being White accrues advantages to a person, without any effort or merit on their part - hence the idea of 'privilege.'

The 1989 article by Peggy McIntosh on White Privilege, cited above, was one of the first to introduce this term into educational scholarship. Today, these Whiteness terms are fairly wellestablished in the field, e.g. a journal Whiteness and Education has been published since 2016, but still far from universally accepted, and actively opposed by politically right-wing and socially conservative factions. As is typical with intercultural topics, the debates have similar contours in each of the above countries, with their analogous histories and educational 
arrangements, but the details in each country differ to such an extent that it is necessary to focus research on one specific context.

This research is centred in Aotearoa New Zealand. Based on a lifetime of personal experience of Māori-Pākehā relationships, and decades of professional practice and research in Māori and Māori-medium education, this article presents an original typology of Whiteness in the form of five categories, or 'avatars' representing major positions taken up by Pākehā. The purpose of this typology is to delineate and differentiate the main attitudes displayed by Pākehā towards Māori in general, as well as in relation to specific situations, in Aotearoa New Zealand. Familiarity with the context is assumed: this is not an introductory article to the social and educational arrangements of Aotearoa New Zealand. This article is based on a non-empirical research approach, building on ideas found in existing literature by both Māori and Pākehā commentators on the intercultural relationship between Indigenous iwi Māori and settler Pākehā of mainly British origin, formalised in the Treaty of Waitangi, which is considered the founding national document for Aotearoa New Zealand (McCreanor, 2005; Nairn \& McCreanor, 1991; Pearson, 1990).

A typology of this nature is best understood as a heuristic device, not a scientific law or rule: a teaching resource for explaining a complex situation, designed to be used as a tool for selfreflection, and for better understanding of the motivations of others. Such a typology works in and with the Foucauldian concept of discourse as meaning 'power-knowledge' - in reference to the way truth is produced through the workings of power, as mediated in language (McHoul \& Grace, 1998; Rabinow, 2010). The 'power' in power relations between Pākehā and Māori is Whitepower, or Whiteness. This particular typology arises from my own experiences of Pākehā people in the workplace and in social situations. As a Māori scholar, I am obliged to think carefully about the non-Māori responses to Māori people and ideas, as I encounter these responses in research and general discourse. Some of the most extreme anti-Māori arguments issue from highly-placed academics and social leaders. The creation of this typology was catalysed by noticing that not all non-Māori attitudes towards Māori visible within educational discourse could fit under one or other of the binary categories of 'Saviors' and 'Allies' presented in an insightful article published in this journal (Cammarota, 2011).

The purpose of Cammarota's binary was to make a distinction between White Allies and White Saviors: those Whites who purport to be allies, but betray other motives by their words and actions in a 'disconnect' that is symptomatic of the White Savior syndrome. The underlying concept of 'Whiteness' can be used to extend this easy-to-remember system, so that it umbrellas a wider range of the Pākehā attitudes seen on display in educational contexts such as schools or universities. My typology contains four positions that act from White Privilege, or Whiteness: two overt - Exterminators and Overlords; and two covert - Vampires and Saviors. Only the fifth position - Allies - works with Māori and against White Privilege.

Choosing theatrical names for the five types draws attention to the key point that marks each distinct theoretical position. Each dramatic 'type' of the 5-point typology includes the word 'White' but for convenience, this word is mostly omitted and assumed, in the text below. The 
typology is marked in use by consistently capitalising the type names in order to denote their theoretical nature. Additionally, the term 'White' is consistently capitalised because it is an identity label: this is a matter of principle, to draw attention to the socially constructed nature of Whiteness, and resist its textual normalisation in scholarship and research literature.

The name 'Exterminator' is chosen because this position maintains that the Māori claim to be a separate ethnic group is invalid. The Exterminator is a 'strong' overt anti-Māori position, while the Overlord is a set of 'weaker' versions of the same overt Whiteness: the Overlord does not deny that Māori exist, but dons the colonial mantle in believing that Māori benefited from being colonised by the British. Holders of this type of attitude often speak as if they feel superior to Māori, and as if they feel personally responsible for 'saving' Māori from their 'benighted' pre-European state.

Vampires and Saviors (American spelling is used for 'Savior'in this article, while noting that 'Saviour' is the standard spelling in Aotearoa New Zealand), on the other hand, display apparently friendly, positive attitudes towards Māori people and topics in education. They consider themselves 'friends' of Māori, and may even profess to consider Māori people as their equals. Covertly, however, these attitudes retain residues of denigratory colonial attitudes towards Māori. When challenged, Vampires and Saviours react with hurt feelings, in displays of White Fragility (DiAngelo, 2018). Importantly, Vampire and Savior attitudes still centre Whites in their social views and relationships with Māori. Vampires want to 'become' or 'consume' Māori: they appropriate Māori things, and often show signs of obsession with their Māori friends. Savior attitudes are weaker, and common in education. Savior attitudes are inherent in the dominant discourses of national history and contemporary society. Such attitudes can therefore be considered the 'default position' for Pākehā who work with Māori in education, including teachers, school leaders, Ministry of Education officers, other relevant statutory bodies, teacher educators, and professional learning providers. The following sections explore each position in detail.

Many Pākehā people hold a personal mixture of ideas and attitudes across the various categories of Savior, Vampire and Overlord, since these ideas are encouraged by the perennial truth-myths about Māori that are dominant in discourses of national identity in Aotearoa New Zealand (Blackburn, 1979). Responsibility for this state of Whiteness must be blamed in part on schooling, whereby generations of children in Aotearoa-New Zealand have imbibed these truth-myths of national identity (in texts such as McDonald, 1963). What I am calling 'truthmyths' are the commonsense notions, such as those listed below, which are generally believed to be true by the Pākehā population of Aotearoa New Zealand. The influence of these truthmyths in the typology of Whiteness will be further explored in the sections below. These ideologies of national history and identity include statements such as:

- There are no 'full' or 'real' Māori left alive any more.

- Māori language and culture are vastly inferior to European.

- Māori were lucky to be colonised by the British and should be grateful.

- Māori have only themselves to blame for their poverty. 
An ethical objection is sometimes raised to conducting debates about Māori-Pākehā relationships in the language of 'Whiteness' terminology, on the grounds that it maintains the central focus on White people, at the expense of attending to the greater needs of the 'otherised' or minoritised group, i.e. Māori in the case of Māori-Pākehā relationships. From a Māori perspective, however, it seems undeniable that Pākehā have absorbed these 'truth-myths' about Māori to a much greater degree than Māori themselves. Pākehā therefore have difficult work ahead, which does not involve Māori people. This difficult change work necessarily starts with greater understanding, to which this typology hopes to contribute. This typology aims to be educational, in the sense that people can change (only) when they learn more.

It seems that racism has many layers, and is more deeply involved in our global society than we may care to think. David Roediger (1999) illustrates this depth by tracing the history of Whiteness in the USA, discussing 'the white problem' - how race was fundamental in the formation of White identity in the emerging nation. "White workers could, and did, define and accept their class position by fashioning identities as 'not slaves' and 'not Blacks"' (Roediger, 1999, p. 13). Racism is pronounced in the US, and cultural influence from the US is immense and ongoing in Aotearoa New Zealand. Current trends towards more extreme forms of Whiteness in US politics (far to the right even of Trump) are therefore also likely to impact in time on Māori-Pākehā relations. The above quote can also be applied to Pākehā identity, since one way of being 'in relationship with' Māori is an active, if perhaps subconscious, rejection of knowing about things Māori. For this reason, I think Whiteness and 'the Pākehā problem' is a crucial, but as yet under-recognised, topic for scholars interested in Māori-Pākehā relationships.

As argued elsewhere (Stewart, 2018a, 2018b), culturally responsive practice in the classroom can do nothing about the soaring levels of poverty among Māori families, caused by the rapid escalation of rents to their current, extortionary levels. And no amount of staff consciousnessraising about the accurate histories of Aotearoa New Zealand can change the ethnic power relations built into how schools, universities, and other social systems operate. 'Racism' is a dirty word and a grave insult in Aotearoa New Zealand, and many Pākehā react with anger if anyone raises the question of racism in their presence. In this way, the reputation for the "best race relations in the world" (Human Rights Commission, 2017) acts to silence any challenge to Pākehā social amnesia and ignorance of their own social history. The whole point of the typology is that most Pākehā are generally operating from a base of ignorance, or insufficient knowledge, about Māori histories and contemporary realities, which prevents them from having the ability to be White Allies to Māori. The typology uses logic (overt and covert, weak and strong) to classify the main ways in which Pākehā, acting from ignorance, respond to the challenge of Māori-Pākehā relationships.

Having sketched the outlines of the topic and the approach taken to writing this article, the next five sections add more detailed commentary on each position of the typology. The conclusion sums up the typology and its potential usefulness in current debates about Māori-Pākehā educational relationships in Aotearoa New Zealand. 


\section{Exterminators - who say there are no 'real' Māori left}

White Exterminators are so called because they deny Māori the right to even exist. Exterminator positions take Māori assimilation to an extreme degree. Throughout the history of the inter-ethnic relationship, Pākehā have expected Māori to assimilate, and the underlying logic of assimilation is to anticipate a time when Māori are 'the same' as Pākehā. The phrase 'politics of identity' refers to identity rights, which include one's right to one's own ethnicity. Assimilation is the denial of identity rights: a form of symbolic annihilation. Hence the metaphor of the 'pest exterminator' is used to name this position.

Colonial Pākehā fantasies of Māori assimilation were initially powered by the doctrines of Social Darwinism, which mis-applied Darwin's then-new biological theories about species formation to the branches of homo sapiens, predicting that Māori would soon 'pass away' before the superior British stock. This evolutionist ideology gave rise to the classic statement attributed to (among others) colonial politician and physician, Dr Isaac Featherston, who in 1856 said that the duty of Pākehā was to 'smooth down the dying pillow' of the Māori race (Pool \& Kukutai, 2019); and the obelisk on the summit of Maungakiekie (One Tree Hill, a volcanic cone and Auckland landmark), in accordance with the original wishes of John Logan Campbell, to "memorialise the Māori race, which he believed was dying out" (Cropper, 2016).

Exterminator thinking moved on in the 1900s (since Māori were clearly not dying out, as predicted by Social Darwinism) and the argument developed that, due to inter-ethnic mixing, there are no longer any 'full' (i.e. 'real') Māori left alive; therefore, there is no distinct Māori population, and hence there should be no 'race-based' policies. Exterminator thinking is thus tied to the first truth-myth listed above in the previous section. Through this reasoning, it has become defensible to argue that Māori equity policies actually create conditions of 'Māori privilege' that are unfair to White and other minority ethnic groups. It is easy to see why these arguments are politically powerful.

The most famous recent deployment of this argument was the Orewa Speech in 2004 (Wikipedia, 2019). In January 2004, Don Brash, formerly Governor of the Reserve Bank, then leader of the National Party, used these arguments in his now infamous speech to the Orewa Rotary Club. In 2019, Brash remains in the spotlight as a spokesperson for the Exterminator position, as upheld by his group Hobson's Pledge (Hobson's Pledge Trust, 2019). Controversial yet tolerated in the liberal sociopolitical milieu of Aotearoa New Zealand, Brash is a local 'media darling' who is regularly asked for his opinion on topical Māori issues. While he and his group are doing little apparent harm, his views support the rise of right-wing politics in Aotearoa New Zealand, and he speaks to conservative wealthy voters, including the Asian populations who now influence election outcomes in a number of Auckland electorates.

The ideas promoted by the Hobson's Pledge group are based on Exterminator thinking: they insist that on signing the Treaty of Waitangi, Māori and Pākehā became one people, apparently not noticing that this blithe rule symbolically annihilates Māori. Brash denounces as 'PC' i.e. 
Political Correctness any position or opinion of which he disapproves. He objects on principle to what he calls 'race-based policy' by invoking the labels of 'separatism' or 'apartheid' accusations with particular resonance in Aotearoa New Zealand because of the history of national protest against apartheid in South Africa, which peaked during the 1981 Springbok rugby tour (New Zealand History, 2018). Brash strenuously denies being a racist by claiming that his views are based on 'facts' in the form of the national truth-myths. This example demonstrates the political influence of these ideologies, which bring the old colonial racist ideas through into the contemporary milieu.

Some scholars in education make analogous arguments, appealing to 'facts' to build apparently strong cases against Māori equity policies and Māori-medium education (Openshaw \& Rata, 2008; Rata, 2012). Careful analysis reveals the argumentative lacunae through which these anti-Māori cases fall apart (Stewart \& Devine, 2019). The faulty arguments usually entail the misapplication of philosophical binaries, such as universalism vs. relativism, to social contexts such as Māori ethnicity.

The basic problem with Exterminator thinking as reflected in the first truth-myth is that it depends on the fallacious pseudo-biological concept of 'race,' which was expunged from the lexicon of science many decades ago, despite still enjoying counter-factual currency in the US. Since 'ethnicity' is a relational concept and not a biological concept, however, Māori identity cannot be determined or limited by 'blood' - so the notion of 'full-blood Māori' is itself racist, along with related ideas such as 'half-caste.' These ideologies, drawn from the same White vocabulary as used elsewhere, have been prominent in ideas of Māori identity in the national imaginary.

\section{Overlords - who say Māori 'owe' Pākehā}

While the name White Overlord sounds extreme, there is an unspoken sense of superiority that underwrites Pākehā cultural domination across the entire social spectrum of Aotearoa New Zealand. The basic Overlord belief is expressed in the second truth-myth listed above, namely, that te reo Māori is vastly inferior to the English language, and Māori culture is vastly inferior to European culture. While it is no longer socially acceptable to refer to Māori people as biologically inferior, Māori culture and language are overwhelmingly seen as primitive, with limited cognitive resources. Within prevailing knowledge frameworks, it is difficult not to understand Indigenous cultures such as Māori as representing earlier stages of human development.

White racist attitudes were fundamental in the British colonization of Māori and Aotearoa. Māori were not wiped out, but instead positioned as a ready-made proletariat class in the emerging modern nation-state of New Zealand (Novitz \& Willmott, 1989). As a result, it is inevitable that Overlord-type attitudes, ranging from subtly invisible to more openly expressed, are exceedingly commonly held by Pākehā in relation to Māori. Overlord attitudes are implicit in local jokes, such as 'Māori time' to mean lack of promptness, a 'Māori job' to refer to a poorly completed task, and a 'Māori day off' for an unjustified absence. For many decades, 
state discourse included explicit discussion of "the Māori problem" (Hill, 2009, p. 92), such as the Hunn Report (Hunn, 1961), described as a comprehensive stocktake of the state-Māori relationship, and "one of the most famous documents of Crown-Māori interaction in New Zealand history" (Hill, 2009, p. 91). Discursively, then, whilst Māori people have been subjected to unrelenting pressure to assimilate, adjectival use of the word 'Māori' invokes the binary of Pākehā superiority/Māori inferiority that sits at the heart of the Overlord attitude.

Already socioeconomically disadvantaged by the ongoing effects of colonisation, during the last 30-plus years the Māori population has borne the brunt of the impoverishing effects on workers of neoliberal policies (Poata-Smith, 2004). As the temper of the times has swung away from traditional support for labour rights, buttressed by a strong social welfare state, Māori families have fallen into poverty at increasing rates, with food insecurity and homelessness emerging as new social realities in 21 st century Aotearoa New Zealand. It is typical of neoliberal thinking to associate wealth with virtue, and hold the impoverished responsible for their own plight. In this milieu, it is unsurprising that the character of the 'Māori dole-bludger' has appeared in public discourse, first introduced in a 1995 prank call to talkback radio from a sitting Member of Parliament (Carlyon \& Morrow, 2013, p. 369).

In 2013, two newspaper cartoons were published that "featured negative depictions of Māori and Pacific people" (Duff, 2017). The images show parents abusing school schemes for providing children with free meals. These cartoons generated widespread criticism, and a complaint to the Human Rights Review Tribunal, but were found not to be unlawful. The cartoonist defended his images, which he said were aimed at "bludgers" and those "on welfare getting handouts" (NZ Herald, 2013), who complained about being poor but who smoked, drank and gambled.

In a 2017 radio interview, business leader Sir Bob Jones echoed these racist views, calling for begging to be made illegal, saying "it's a disgrace in a modern society that fat people - that fat Māoris as they mostly are - are lying on our streets of our city begging" (NZ Herald, 2017). He went further in 2018 in proposing a 'Māori Gratitude Day,' saying:

"as there are no full-blooded Māoris in existence it indisputably follows that had it not been for migrants, mainly Brits, not a single Māori alive today ... would have existed". Ergo, he continued, “it's long overdue for some appreciation. I have in mind a public holiday where Māori bring us breakfast in bed or weed our gardens, wash and polish our cars and so on, out of gratitude for existing." (The Spinoff, 2018)

This quote clearly shows how the truth-myths of national identity feed such Overlord opinions. While all these overt examples have generated controversy, the bigger point is that expressions of Pākehā superiority, usually in much more subtle terms, are the norm, rather than the exception, of life in Aotearoa New Zealand (Moewaka Barnes, Taiapa, Borell, \& McCreanor, 2013). 


\section{Vampires - who want to 'consume' Māori}

White Vampires are inclined to want to get too involved in Māori affairs. This category or avatar covers a range of positions from stronger to weaker, but Vampire attitudes are invariably duplicitous: apparently friendly on the surface, but ultimately centred on the Pākehā person's interests, not those of the Māori person who may be the centre of their attention. I have heard it said by Māori politicians 'At least with Don Brash what you see is what you get,' meaning, Brash says what he thinks, and his overt racism can be dealt with. This statement implies the shadow thought: it is worse for a Māori person to become friends with a Pākehā, only to gradually realise that they see you, not as a full person in your own right, but as a resource in human form they can use for their own ends. Bingo - you've made friends with a White Vampire.

Vampires often seem to find it hard to understand what they think they need to know about Māori: no matter how much time and help Māori colleagues give them, they still don't 'get it'. Each new Māori person they encounter becomes their new 'object of desire'. Some Vampires wear their cultural responsiveness like a badge: they may remind their audiences that they are Pākehā (as if anyone had forgotten) so therefore not the right person to speak to Māori issues, before doing so anyway. Some Vampires adopt Māori mannerisms and habits; some may even give themselves Māori names, or draw a veil over their non-Māori ethnicity.

Recently, in a dramatic example of White Vampire attitudes, a Pākehā woman who got a moko kauae (traditional female chin tattoo) caused a media frenzy and a Māori backlash (NZ Herald, 2018). Māori reserve the right to wear moko kauae for those who can demonstrate their Māori lineage. Without such links, a moko kauae easily becomes merely a form of 'make-up' somewhat reminiscent of 'blackface' - the now-despised use of theatrical make-up, associated with a US-specific racist type of performance art known as 'minstrelsy' in which White performers parodied people of African descent (University of South Florida Libraries, 2020).

Vampire attitudes include the senior person who expects their Māori colleague to say karakia (grace) before each staff morning tea, do a mihi (speech) at formal events, or arrange a pōwhiri (welcome ceremony) for departmental visitors. At first the Māori person will be credited for their efforts, but very quickly it becomes an expectation, and they will be seen as neglecting their duties if they do not oblige. Māori people working in education have usually been generous in responding to these requests from their Pākehā friends and colleagues, reasoning that it is better to have some presence for Māori culture in national life than none at all, while also usually painfully aware of the paradoxes and personal costs involved (as explored in Stewart, Tamatea, \& Mika, 2015).

Current national Māori education policies may actually encourage Vampire and Savior attitudes and responses in professional practice, with the exact nature of the response depending on the individual situation and person involved. But without accurate knowledge of Māori and Pākehā histories and contemporary realities, in trying to demonstrate cultural responsiveness, 
Pākehā teachers are very likely to enact Vampire or Savior attitudes when including Māori content into their classroom practice.

\section{Saviors - who see themselves as helping Māori}

The White Savior syndrome is the default attitude among Pākehā who work in education, almost all of whom are genuinely concerned to help Māori students succeed. Although a person with White Savior syndrome appears positive and supportive towards Māori things and people, since they have not resolved those ideologies of nationality, they are also racist at deep, unconscious levels. There are various ways in which these 'subterranean' levels of racism come to the surface in language (Wetherell \& Potter, 1992); the way pronouns ('we/us' and 'they/them') are used when referring to Māori and Pākehā, for example, is usually a giveaway of Eurocentric perspectives.

A more complex example of the White Savior syndrome is displayed by the person who believes their organisation supports biculturalism by including pōwhiri, karakia and waiata in the workplace culture, while also simultaneously believing that Māori parents' lifestyle choices and poor decisions are the cause of the educational underachievement of their children. For a Pākehā person to believe that their role as an educator is to 'help' Māori betrays an underlying deficit belief that Māori 'need' Pākehā to help them. The complex and nuanced distinctions between these attitudes mean that Pākehā can often end up feeling as if they are 'damned if you do, and damned if you don't' - and Māori education professionals are also vulnerable to this same feeling, of being caught as if in a trap. To confront the past and present racist oppression of Māori people, language and culture, on which Aotearoa New Zealand operates, is demanding work on a number of levels, cognitively and psychologically, for all concerned.

An extremely common reaction by Pākehā people in education is to take offence when a colleague or presenter raises uncomfortable aspects of Māori perspectives on things. I have come to understand this Pākehā reaction of 'taking it personally' as a local New Zealand version of Whiteness in the same sense as 'white women's tears' in the US, which is the topic of a chapter in White Fragility (DiAngelo, 2018). To see it as a personal attack when a colleague or presenter speaks about generic Māori issues is a sure sign of Whiteness, because it centres the Pākehā person's feelings of offence, and makes wrong the person causing that discomfort for speaking in that way about what might be 'inconvenient truths'. Most Pākehā people in education workplaces are happy enough to have mihi (speeched) or waiata (group singing) included as part of meetings or events, but many of those same people will take umbrage at any suggestion that what they are doing is not enough to make an effective difference for Māori in education. Ironically, the subtle eddies of intercultural misunderstanding mean the Māori person who is standing up for a whole history of national oppression is often seen as behaving inappropriately. In such moments, people "tend to adopt roles [such as] 'Angry Māori' [and] 'Defensive Pākehā'”' (Consedine \& Consedine, 2012, p. 185 ) - or have these roles assigned by others, who may also lack of understanding of what is being said. 
Such taking of offence is part of the White Savior syndrome, because Savior logic for Pākehā includes willingness to 'do the right thing' in return for being credited with compliance with cultural responsiveness, diversity, Treaty of Waitangi, biculturalism, or whatever terms are used. Pākehā people working in education often feel 'vulnerable' when they take steps to include te reo and tikanga in workplace practice: scared of 'getting it wrong' and unable to tolerate any perceived criticism of what they have done. In this way, the vulnerability is shifted away from Māori, and towards the Pākehā educator. Increasing demands on educators to include te reo and tikanga in their professional practice, without acknowledging how accurate histories of Māori-Pākehā relationships have been forgotten and replaced by a triumphal White narrative, will inevitably result in more of this kind of 'vulnerable Savior' behavior.

\section{Allies - who relate to Māori as different but equal}

White Allies, unlike those who hold the attitudes already covered, have done the work - the reading, listening, and thinking - required to apprehend and work through the truth of history and ideas about the Māori-Pākehā relationship that make Aotearoa New Zealand the country it is today. Allies easily see through the rhetorics of Brash and his ilk, and pay no attention to the White propaganda issuing from right-wing lobby groups.

White Allies are those Pākehā people who cause me to forget they are non-Māori: not because they pretend to 'be' Māori, but because their political viewpoint on Māori issues aligns with my own. I sometimes think of my White Ally friends as 'honorary Māori' - which is paying them a great compliment. White Allies are my favourite non-Māori people to work with: it is refreshing, and not the norm, to talk about topics in education with colleagues who have a strong level of understanding of Māori issues. There are, however, vastly insufficient numbers of Pākehā working in education who hold White Ally attitudes, compared with what would be needed in order to make a statistically significant difference to Māori-Pākehā relationships.

Some may ask for more detailed explanations about the avatar of the Ally and how a person can be encouraged to 'grow' into this identity, but to reduce the category of the Ally to some formulaic set of competencies that can be prescribed, learned and assessed seems to betray something of its very essence. I believe there are as many ways for a non-Māori person to be a White Ally to Māori as there are non-Māori people working in education. What is always required, however, is a willingness to invest the time required to read, think and expand one's horizons of knowledge. Since time is invariably in short supply for an education professional, this willingness to 'do the work' demonstrates the high value that White Allies place on better understanding the historical bases of their cross-cultural relationships with Māori. This willingness to admit to not knowing; to the impossibility of knowing the cultural Other, is, as the saying goes, half the battle, but results for those individuals who do so are often 'priceless'. But the starting point and exact pathway for the person who wishes to become an Ally cannot be prescribed in advance: it is unique, and up to each one to find for themselves. 


\section{Conclusion}

My typology of Whiteness works as a heuristic because the categories are easy to remember. It is an embedded, provocative form of theory-making, not a scientific theory based on mathematical laws, but maybe useful nonetheless for generating deeper understanding about the complex intercultural relationship between Māori and Pākehā in education. I extended the original binary categories of Saviors and Allies (Cammarotta, 2011) by adding three more: Exterminator, Overlord and Vampire, to allow the typology to capture more of the attitudes seen when Pākehā people, working in education, respond to Māori language, culture, perspectives or people. While the category or avatar names are based on metaphor and exaggeration, the typology reflects the reality of working conditions in contemporary (2020) educational contexts in Aotearoa New Zealand. It cannot be generalised, but its patterns are likely to resemble those seen in other CANZUS contexts.

Understanding how the five categories work, and why only one category, the Ally, robustly supports Māori interests, allows the typology to be applied to thinking about Māori-Pākehā relationships. These are complex issues, and misunderstandings are rife. Even with the best of intentions, to address the history and contemporary experiences of Māori in an educational workplace is inevitably a minefield of confusion and upset feelings. A typology helps us organise our experiences into patterns, which lets us get beyond seeing each encounter with Whiteness as a separate occurrence. Referring to the typology may help with thinking through negative reactions or feelings that arise in particular situations involving specific friends or colleagues.

A typology is a form of theory-making, and this typology originates in my own experiences and readings, which makes it a kind of 'grounded' theory, deriving from analysis consistent with the principles of Kaupapa Māori theory (Stewart, 2017). I think of this typology as a product of my grounded Māori philosophy of education. The edifice of racism on which our nation states are built cannot be taken apart by writing a typology, an article or a policy. But in taking seriously the Foucauldian concept of discourse as power-knowledge, this research recognises the need for new theories and languages, new ways of talking about Māori-Pākehā relationships that more accurately convey Māori perspectives, to help all of us navigate the difficult territory of the liminal intercultural space.

\section{References}

Blackburn, A. (1979). Racial harmony in New Zealand: a statement of issues. Wellington, New Zealand: Human Rights Commission.

Bonilla-Silve, E. (2005). 'Racism' and 'new racism': the contours of racial dynamics in contemporary America. In Z. Leonardo (Ed.), Critical pedagogy and race (pp. 1-35). Malden MA: Blackwell.

Cammarota, J. (2011). Blindsided by the Avatar: White saviors and allies out of Hollywood and in education. Review of Education, Pedagogy, and Cultural Studies, 33(3), 242259. https://doi.org/10.1080/10714413.2011.585287 
Carlyon, J., \& Morrow, D. (2013). Changing times: New Zealand since 1945. Auckland, New Zealand: Auckland University Press.

Consedine, R., \& Consedine, J. (2012). Healing our history: the challenge of the Treaty Of Waitangi (Updated ed.). Auckland, N.Z.: Penguin NZ.

Cropper, E. (2016). NZ statues linked to genocide, racism. Retrieved from https://www.newshub.co.nz/home/new-zealand/2016/04/nz-statues-linked-togenocide-racism.html

DiAngelo, R. (2018). White fragility: why it's so hard for White people to talk about racism. Boston MA: Beacon Press.

Dorrien, G. (2018). Breaking white supremacy: Martin Luther King Jr. and the black social gospel. New Haven CT: Yale University Press.

Duff, M. (2017). Controversial Fairfax Media cartoons could have made racism against Māori worse, panel member says. Retrieved from https://www.stuff.co.nz/national/99124605/controversial-fairfax-media-cartoonsinsulting-judge-says

Hill, R. S. (2009). Māori and the State: Crown-Māori relations in New Zealand/Aotearoa, 1950-2000. Wellington, New Zealand: Victoria University Press. Retrieved from http://nzetc.victoria.ac.nz/tm/scholarly/tei-HilMaor-t1-body-d5-d2.html

Hobson's Pledge Trust. (2019). Honour Hobson's Pledge: he iwi tahi tātou - we are now one people. Retrieved from https://www.hobsonspledge.nz/

Human Rights Commission. (2017). Race Relations Commissioners and Conciliators mark significant anniversary. Retrieved from https://www.hrc.co.nz/news/race-relationscommissioners-and-conciliators-mark-significant-anniversary

Hunn, J. K. (1961). Report on Department of Maori Affairs: with statistical supplement. Wellington, New Zealand: Government Printer.

McCreanor, T. (2005). 'Sticks and stones may break my bones...': Talking Pākehā identities. In J. H. Liu, T. McCreanor, T. McIntosh, \& T. Teaiwa (Eds.), New Zealand Identities: Departures and Destinations (pp. 52-68). Wellington, New Zealand: Victoria University Press.

McDonald, K. C. (1963). Our Country's Story: an illustrated history of New Zealand. Auckland: Whitcombe \& Tombs

McGettigan, T. (2019). Terminating White Supremacy: Democracy for All. Retrieved from https://ssrn.com/abstract=3475509 https://doi.org/10.2139/ssrn.3475509

McHoul, A. W., \& Grace, W. (1998). A Foucault primer: discourse, power, and the subject. Dunedin, N.Z.: University of Otago Press.

McIntosh, P. (1989). White privilege: Unpacking the invisible knapsack. Peace \& Freedom Magazine(July/August), 10-12.

Moewaka Barnes, A., Taiapa, K., Borell, B., \& McCreanor, T. (2013). Māori experiences and responses to racism in Aotearoa New Zealand. MAI Journal, 2(2), 63-77.

Nairn, R., \& McCreanor, T. (1991). Race talk and commonsense: Patterns in Pākehā discourse of Māori/Pākehā relations in New Zealand. Journal of Language and Social Psychology, 10(4), 245-260.

Novitz, D., \& Willmott, B. (Eds.). (1989). Culture and identity in New Zealand. Wellington: GP Books. 
NZ Herald. (2013). Cartoonist won't apologise for 'racist' images. Retrieved from https://www.nzherald.co.nz/nz/news/article.cfm?c id=1\&objectid=10887468

NZ Herald. (2017). Sir Bob Jones labels beggars a 'disgrace to society' Retrieved from https://www.nzherald.co.nz/nz/news/article.cfm?c id=1\&objectid=11783845

NZ Herald. (2018). Pākehā woman with tā moko accused of cultural appropriation. Retrieved from https://www.nzherald.co.nz/nz/news/article.cfm?c id=1\&objectid=12057551

Openshaw, R., \& Rata, E. (2008). Flax rope or iron fetter? how cultural essentialism threatens intellectual freedom in the New Zealand tertiary education sector. New Zealand Journal of Tertiary Education Policy, 3(1), 1-27. Retrieved from https://teu.ac.nz/2008/12/the-new-zealand-journal-of-tertiary-education-policy/

Pearson, D. (1990). A dream deferred: the origins of ethnic conflict in New Zealand. Wellington: Allen \& Unwin.

Poata-Smith, E. (2004). Ka Tika A Muri, Ka Tika A Mua? Māori Protest Politics and the Treaty of Waitangi Settlement Process. In P. Spoonley, C. Macpherson, \& D. Pearson (Eds.), Tangata Tangata (pp. 59-88). Southbank: Thomson/Dunmore Press.

Pool, I., \& Kukutai, T. (2019). Taupori Māori-Māori population change - Decades of despair, 1840-1900. Retrieved from https://teara.govt.nz/en/taupori-maori-maoripopulation-change/page-2

Rabinow, P. (Ed.). (2010). The Foucault reader. New York NY: Vintage Books.

Rata, E. (2012). Theoretical claims \& empirical evidence in Māori education discourse.

Educational Philosophy and Theory, 44(10), 1060-1072. https://doi.org/10.1111/j.1469-5812.2011.00755.x

Roediger, D. R. (1999). The wages of whiteness (Rev. ed.). London \& New York: Verso.

Stewart, G. (2017). Kaupapa Māori theory as a philosophy for education. In T. K. Hoskins \& A. Jones (Eds.), Critical conversations in Kaupapa Māori (pp. 133-146). Wellington: Huia Publishers.

Stewart, G. (2018a). Accurate histories, critical curriculum: a conversation with Tamsin Hanly. Curriculum Matters, 14, 69-86. https://doi.org/10.18296/cm.0030

Stewart, G. (2018b). Te whai mātauranga: he painga mō te tangata kotahi pea, mō te iwi katoa rānei? Education: a private commodity, or a public good? New Zealand Journal of Educational Studies, 53(2), 165-176.

Stewart, G., \& Devine, N. (2019). A critique of Rata on the politics of knowledge and Māori education. Waikato Journal of Education, 24(1), 93-101. https://doi.org/10.15663/wje.v24i1.665

Stewart, G., Tamatea, K., \& Mika, C. (2015). Infinitely welcome: education pōwhiri and ethnic performativity. MAI Journal, 4(2), 91-103.

The Spinoff. (2018). Bob Jones and NBR divorce over 'Māori Gratitude Day' column.

Retrieved from https://thespinoff.co.nz/media/07-02-2018/bob-jones-and-nbr-divorceover-maori-appreciation-day-column/

University of South Florida Libraries. (2020). Minstrelsy. Retrieved from https://exhibits.lib.usf.edu/exhibits/show/minstrelsy

Wetherell, M., \& Potter, J. (1992). Mapping the language of racism: discourse and the legitimation of exploitation. New York: Harvester Wheatsheaf. 
Wikipedia. (2019). Orewa Speech. Retrieved from

https://en.wikipedia.org/wiki/Orewa Speech 